\title{
Integrating the youth into the life and work of the church through education
}

Dr N. P. Heystek

\section{DEFINITION OF KEY WORDS (Part one)}

1.1 The church as phenomenon and the position of the youth in the church Although quite a few images or phrases are used in the Bible to describe the church, we shall use only two in this presentation, namely: the church as body of Christ (Rm 12:4-5;1 Cr 12:12 f, Cl 1:24; Eph 4:11) and as flock of God (Jn 10:1-18; 1 Pt $5: 2$ ). These two images constitute:

The church as an organism - as close and intimate as the human body. In this organism all the specific members must feed one another, care for one another, and assist one another, otherwise it is impossible for this body to function and to be of service (e.g. $1 \mathrm{Cr} 12: 13 \mathrm{f}$ ).

Applied to our subject it means that the youth occupies a specific area of the church as body and fulfills specific functions. In closer examination it is possible to say that the youth can be identified as the young cells and elements of renewal in the body. This, to a great extent, contributes to regeneration and an accelerated life. When youth has no standing in a church, or is overlooked in the role it has to play, the body will grow old ... and eventually die off.

In the church as a body, Christ has a cardinal role, because He is the Head (kephalé; Eph $1: 22,23 ; 4: 15,16 ; 5: 22-31 ; \mathrm{Cl} 1: 18 ; 2: 19$ ). Through Him as Head, the body is created and also exists. This is the reason, in short, why the church is called the body of Christ. The inseperability of Christ and the church is stated, without the two being identified (Van der Walt, 1976:47). Christ maintains and protects His church by, amongst other things, adding young members to it; all those that were given to him by the Father (Jn $17: 9$ ). The reason for Christ being the head of the church is to be found in his work of reconciliation and of redemption (Jn $6: 47-48)$.

Summary: The church is a creation of God, through and in Christ (the service of the Holy Spirit set aside for now). Christ serves and supports his church eternally. The church never becomes obsolete and never perishes. As older members die an earthly death, other (mostly younger) members take over; so the body reproduces itself, in Christ, through faith. In this body the older and younger members have an interrelated beneficial influence on one another.

- The church is the flock of God (Jn $10: 1-18 ; 1$ Pt $5: 2$ ). In the flock of God there are fullgrown sheep (probatia ; Jn 15:16;10:11) and lambs (arnia; Jn $21: 15$ ). Jesus is the Chief Shepherd of all of these (1 Pt $5: 4$; argepoimenos). Nevertheless, Jesus uses instrumental shepherds like Peter (1 Jn $21: 15 \cdot 18)$ and the elders (1 Pt $5: 1 \mathrm{f})$ to care for his flock. But Christ himself is also the gate to his kraal; nobody can join the flock if he does not accept Christ as redeemer ( $\mathrm{Jn} 10: 11,18)$. The flock is safe under the authoritative voice of Jesus, as it is embodied in the Bible (Jn 10:4: Hb 1:1 f). The fact that Jesus gave the little ones (small 


\section{In die Skriflig}

children) a safe place in his flock, went against the spirit of the time, because children were treated with contempt (e.g. Mt 19:14;18:2-5; Mc $9: 36 ; 10: 13-15,0)$. In the synagogue, boys were, from the age of twelve, accepted as full members.

Summary: A flock without lambs is a dying flock. Jesus looked onto the children as a essential part of the flock; on the strength of their parents belonging to the church, they were integrated (covenant). In the living together with the rest of the flock, these lambs are taught and showed the full meaning of belonging to a church, and in the flock they are cared for. Christ himself primarily takes care of his flock in the sense that he is the Chief Shepherd and the door.

\section{Conclusive Summary}

The youth forms a necessary and essential part of the church as body of Christ and flock of God. He who neglects the youth is playing with the life, function and future of the church.

With this the place of the youth in the church is established.

\subsection{The life and work of the church}

The above mentioned two images express the mode of existence and nature of the church, but do not articulate the life and work of the church as such. For this purpose we have to explore different sources from Scripture.

\section{Beforehand the following:}

Many people ask for greater activity of the church in the world today, because they are of opinion that the church is losing some of its power and influence ... . or has done so already. Therefore the plea for greater involvement in current political, social, economical, labour and other issues is heard. The church as an organization must make itself heard, state its claims, and promote its own spokesmen and executives. The question we must ask, however, is whether this can be verified to Scripture.

To my opinion, the church has a life and work aimed internally, as well as externally. These two dimensions stand in the above mentioned relation to each other. The life and work of the church externally, follow out of its internal life.

The internal life is possibly expressed clearest, to the core, in Eph $4: 12$ ... to prepare God's people for works of service, so that the body of Christ may be built up ... (New International Version).

Three crucial words are used here, namely: 'prepare', 'service' and 'built' (up). These three concepts are tied to the church as body of Christ. This life, service, and build up internally, are described in a number of places in the New Testament, but most clearly in Ac 2;42 - 46 and Ac $4: 32$ - 35, where the following aspects are named:

- Persistence in the teachings of the apostles;

- persistence in koinonia;

- persistence in prayer:

- persistence in the breaking of bread.

Out of this internal growth, life and work of the church flow in an organical way to the life and work of the congregation externally: 
- The Gospel is preached everywhere (Ac $5-8 \mathrm{f})$;

- a holy life is lead in a pagan milieu (1 Pt $4: 3,4)$;

- the members serve, are friendly and full of self-control (Rm $12: 1$; Jn 1:6;2 Tm 1:7).

Conclusion: - They are the salt of the earth and the light of the world (Mt $5: 13,14$ ).

- They need not become the above mentioned, they are so already.

\section{Summary}

The life and work of the church has a two-way action occuring simultaneously, namely: an internal building and schooling, and an external sharing of that which already belongs to the church. The church should not look for actions and causes in an attempt to establish a standing. The church already has a standing, a name, almost unexpressively exalted: body of Christ! The church should only live what it already is, salt and light for the earth.

In the church as an organism, the youth is brought up, equipped, lead to share in the responsibility of the church's existence and therefore to serve the Lord optimally in the church and in the world. Life in isolation within the church, becomes a sterile existence, because one member needs the other.

\subsection{Integrating the youth into the church}

The youth is integrated into the church in the following way:

- Birth into the bond of the covenant (Gn $9: 9 ; 15: 18)$;

- lawful adoption (Gn 17: 11 f)

- confession of faith and baptism (Mt $28: 18,19 ;$ Ac $2: 39$ ).

No other way is possible.

As members of the Reformed Church community it's taken for granted that all of us accept the teachings of predestination, covenant and baptism of babies. Legal adoption is also a means of accepting a child into the community of the church (e.g. RES-conclusions). As for the fact that integration into the church also happens by way of public witnessing of faith, where upon baptism follows, there exists a worldwide consensus.

\section{Summary}

The youth is integrated into the church as an organism, whether by organical implantation through birth by means of the covenant of God; whether by legal adoption by faithful parents, or through personal witnessing of faith and baptism in the Name of the Holy Trinity.

- Out of the above mentioned statement it seems that faith plays a cardinal role with the parent accepting the promises of God, as well as with the youth concerned (confession).

- Faith comes from the Holy Spirit (e.g. Eph $2: 8$ etc.). Therefore, it is God Himself integrating his youth into the church. God only uses parents, prophets and teachers to be his instruments in this matter (Jn $21: 15$ 18).

1.4 Education as method to intensify the integration of the youth into the life and work of the church

There are various ways by which the intensifying of the process of integration of the youth into the church can come about, namely: church 
services, Bible study, missionary work, evangelisation, youth camps, small group koinonia, and involving the youth in all matters of church life. One of the best ways - a God chosen way - is education. In the next paragraphs we will look more closely at this God given way, by means of which the lambs can be integrated more intensively into the church.

\subsection{Conclusion of part one}

God Himself puts the church into existence; he Himself supports his church; he Himself integrates the lambs into the flock in an original way. The church is founded on faith, created by God through his Word and Spirit, with a strong Christological accent. The church as communion in faith, forms in an organical way the body of Christ, continually regenerating itself from within to become even more what it is, namely the light and salt of the earth. One of the most important methods to intensify the integration of the youth into the church is by means of education.

The description of this way of integration hereby follows:

\section{EDUCATION AS METHOD TO INTENSIFY THE LIFE AND WORK OF THE YOUTH INTO THE CHURCH (Part two)}

\subsection{Education as a God given method}

There are various systems of education to be found: school, university education, labour schooling, training on the job, learning of social skills, assimilation of technical skills. In everyday life it is clear that a child must come to adulthood by means of learning. The whole society rests on, and is carried forward, by teaching and training. The church is no exception to this rule. Therefore, the Lord gave the church from the beginning a command to train (e.g. Ps 78; Jh $21: 15$ ); not only this, but God also gave the instruments (teachers), as well as the contents (syllabus) and a Chief Educator (the Holy Spirit: Ac $2: 17$ ). This is substantiated in the following paragraphs.

\subsection{The relation between education and modelling}

It is generally acepted that example setting (modelling) can be regarded as a stronger educational instrument than verbal tuition. This is true to a great extent. But I am of the opinion that it is not beneficial to weigh these two methods against one another.

Modelling set the example, shows the way and the deed in a concrete manner; but verbal tuition corrects, motivates and sets the ideal. One without the other is unthinkable (e.g. James; Rm 12:12 f; Gl 4, 5).

Summary: Example and verbal tuition form a two-unit; the one unthinkable without the other. The deed realises the truth of the Word and life with God; while verbal tuition explains, corrects, inspires, idealises . . .

\subsection{Youth education in the Old Testament}

Although the church as the body of Christ isn't found as such in the Old Testament, Israel was in a very specific manner people of God already; and the lambs (youth) were educated to adulthood, and fully integrated into the life and service of the flock (Israel), in the following ways:

- teaching and abiding in the law (e.g. Exodus to Deuteronomy); 
- tuition during national festivals, and taking part in the festivals (e.g. Passover, Purim Feast, Feast of the Tabernacles, and Day of Reconciliation, etc.; Lv $23: 27,28)$.

- tuition in the home (Dt $6 ; 11 ;$ Ps 78 ; etc.);

- tuition in the temple (De Vaux. 1973:50; Lv $10: 11 ; 2 \mathrm{Kn} 12: 2$ );

- tuition in the synagogue (from \pm 430 B.C.).

In the next paragraphs each of these areas is discussed in short.

Teaching and abiding in the law

The meaning and function of the law in the Bible is rich and varied (e.g. Ps 19;119; Rm 2: 7; Gl 2-4; Ridderbos. 1966:139-1 65). It is not our intention to dwell on all these aspects, although most of it were most certainly applicable to the children. We want to stress the following:

- In the law (as concentrated in the Ten Commandments) the foundation for the sanctification of life was lain: whoever knew it by heart and lived by it, was able to live beneficially with God and neighbour (e.g. Mt $22: 37-40 ; \mathrm{Rm} 7: 12$ ) ; because the law revealed His expectation of man in regard to Himself, in regard to Israel as a people of God, and in regard of the pagan nations. In this respect the value of the law can never be over-estimated.

- The value of the law was realised by its mediator (Moses), and repeated in Deuteronomy. Later it was systematically repeated in the synagogue. The churches realise the worth and function of the law to this day and therefore it is assimilated and applied liturgically.

- The law as code of the covenant may still not be neglected. Its application in the Heidelberg Catechism was well founded and therefore it should still be taught and preached. The theological and practical significance of the law, especially as given by Paul to the Romans and Galatians, should still be passed on to the children. The standing and the explanation of the law in the Heidelberg Catechism can still be regarded as one of the most illuminating and glorious thereof. Nobody is saved through abiding the law, but nobody can be saved without abiding the law (James). What is applicable to the individual in this case, is also applicable to the church as body.

\section{Home education}

Home education is the primary locus for nurturing ( $2 \mathrm{Sm} 4: 4)$. For this there is no better institution or no substitute; in case of the home education presented with real seriousness and ability. The instructions of God are very clear in this regard (e.g. Dt $6: 6-13 ;$ Dt $11: 19-21 ;$ Ps $78: 3$ 8: Pr $4: 1$ - 4 etc.) The home education should take place in an atmosphere where the family lives in a daily liturgy with God (Dt $6: 7)$, and where everything around one reminds one of God (Dt $6: 8$ ).

The ideal is to influence the school, university, colleges and the whole environment, in such a way as to continue the home atmosphere and build on to it. Alas, this is only an ideal, because believers are few and strangers in the world $(\mathrm{Jn} 17: 13-17 ; \mathrm{Hb} 11: 9-10)$. The following statement made by Richards is considered very important. I quote: We must begin to think of Christian education as the teaching and learning of Christian faith as culture not merely as the communication of true information about life and the Bible (1972:45). 


\section{In die Skriflig}

Summary: Home education should take place in an atmosphere and life style constantly devoted to God;

Intense connections with the congregation should also be realised, because the family is a cell in the body (Louw, 1980:59); the character of the home should be carried out, and lived into a secular world.

\section{Education through national festivities}

Every national festivity was a wonderful possibility to recall the deeds of God in a theoretical as well as a practical way, and to renew contact with Him. Some of these festivities were celebrated on a family basis (e.g. Passover), and bound the family together and to God; others were national feasts, where the unity of the nation was accentuated (e.g. Day of Atonement; Purim Feast). Apart from these, Israel kept many memorial places (Bet-el, memorial stones commemorating passing through the river Jordan). The place and meaning of family and national (church) feasts and religious monuments carried a meaningful influence.

Summary: God used family and church festivals in Israel to bind the people to Him on a constant basis. Perhaps this method could be used more readily during family, congregational, and denominational festivals, to bind the youth to the past. Erecting church monuments is another way to achieve this goal.

\subsection{Priestly, prophetical and synagogical education}

Apart from home education, where boys and girls were educated by both parents (Ec $1: 1 ; 6: 20 ;$ Ex $10 ; 2 ; 12: 26$ etc.), the boys received further education through specially ordained priests (e.g. $1 \mathrm{Sm} 2: 21 ; 26 ; 2 \mathrm{Kn} 12: 3$; De Vaux, 1973:50).

Alongside the priests, the prophets acted as teachers. The prophets, too had a mission to instruct the people; this was at least as much a part of their task as foretelling the future (De Vaux, 1973:50). Along with them wise men taught men how to live a good life (e.g. Ec $1: 20 \mathrm{f} ; 8: 2 \mathrm{f}$ ).

Since earliest times the synagogues had their own schools, where the boys were instructed up to the age of twelve. Instruction in the law was in the centre of this training. The synagogues originated as a substitute for temple service after the demolition of the temple and during exile. Jerusalem as city, had during the time of Jesus no less than 480 synagogues. The synagogues caused the transition from informal institutionalised religious instruction to formal church instruction.

Summary. Apart from the education in the homes, which is to be accepted as the primary instrument in education and training, officials were ordained from the earliest times to support the home education. Although it was initially restricted to temple education, it was extended during the synagogical period (though restricted to include only boys) .

\subsection{Education in the New Testament}

The New Testament gives no explicit instructions as to youth education and training, as far as the church is concerned. It can be accepted that the principles and commands of the Old Testament are presumed. From certain statements of Jesus, and the instructions included in the 'home tables', it is clear that the children in the New Testament were fully 
accounted for in the church and were educated in the context of the congregation (e.g. $1 \mathrm{Tm} 5: 1$ - 11).

The following statements and actions of Jesus are considered important:

- He embraced the children as a sign that they belonged to him (Mc $10: 16)$;

- He used the child as comparison in his teachings (Mc $9: 36,37$; Mt $18: 1-10)$.

- He directed serious warnings to those causing a child to stumble (Mt $18: 5,6)$;

- He noticed the disposition and aims of the church in a child (Mc 9: 33 - 37; Lk $11: 13$ ).

The following aspects of the 'home tables' are referred to:

- Relationships between children and their parents (Eph $6: 1-4)$.

- Obedience shown by the children in respect of the parents $(\mathrm{Cl} 3: 20)$. Apart from two groups of statements, it is important to keep in mind that the two books written by Luke (his gospel and the Acts), are in essence catechetic works, because they were written to Theophilus as continued catechism (e.g. Lk 1:1-4). The contents, aim and method of catechism can make fruitful use of these two books.

Lastly it is pointed out that the case of training in the church according to the New Testament, is of fundamental importance. The congregation is continually called upon to teach one another, and by doing so strengthen one another (Ac $2: 42-46$; Eph $4: 11 \mathrm{f} ; \mathrm{Cl} 3: 16$, etc.). Logically the teaching will be directed primarily to the children.

Summary. - The New Testament does not provide as much explicit material on youth education and training as the Old Testament, because the Old Testament teachings are presumed.

- Nevertheless it is clear that Jesus (against the spirit of the times) gave the child a position of honour with Him, in society, and especially in the church. As far as the 'home rules' are concerned, it is clear that Paul regarded correct and Biblical education as of the utmost importance. This is also clear from the writings of Luke as well as from the mutual encouragement to education.

2.6 Education in the history of the church (catechism)

In this regard we will give only three viewpoints, to show that training of the youth was (throughout the history of the church) regarded as of utmost importance. Firstly we will discuss conclusions of the apostolic fathers, afterwards the Synod of Dordt (1618/19), and lastly the viewpoint of the Reformed Churches of South Africa. This is done in short.

Pronouncements of the Apostolic fathers

Polycarp, on his way to Rome, where he was convicted and at the age of eighty died a death of torture, wrote to the congregation of Philippi: Let us teach, first of all, ourselves to walk in the commandments of the Lord. Next, teach your wives . . . and train your children in the knowledge and fear of God ( $4: 2$; Richards, 1983:37). Clemens wrote in his letter of admonition to the Corinthians: Let children partake in the training that is in Christ (21: 7 - 8; Richards, 1983.37).

Resolutions at Dordt (1618/19)

The synod decided on tri-une catechism (e.g. De Villiers, 1957:120-123) : 


\section{In die Skriflig}

In the home by the parents (form and content)

Joint Scripture reading and prayers; principles and content of religion explained to children; taking children to church services and relating of sermon about catechism to them. Anybody neglecting these commands was chastened.

At school by the teachers

Teachers had to underwrite the Belgic Confession of Faith and the Heidelberg Catechism. For at least two days a week they had to train the children in the Heidelberg Catechism and explain its contents; for this purpose three books were composed (for different ages).

At church by ministers

Ministers had to preach the catechism weekly in such an uncomplicated way that children could understand it. Older people had to receive training during the week (the curate could be of help in this way).

Summary: The Synod of Dordt established an important organical connection between home, school and church. The subject matter was, with the catechism as basis, dogmatic in content. It was seen as a concise summary of Biblical promulgation.

The Reformed churches of South Africa's point of view

The viewpoints of the Reformed Churches, as given during synod meetings, especially in the period 1928 - 1979, were as follows:

Catechism and training of the youth in the church is an official command of, and service by Christ, as far as the church is concerned, and specifically the church officials. This service complements the parental training which is primary.

The goal of catechism is to lead the youth to adulthood in faith and service in the church and world; as well as to assure partaking in holy communion.

Training does not stop when public confession of faith is completed, but is a life long task continuing especially through the preaching of the Heidelberg Catechism and through youth activities. In all training at the church, the Bible occupies the primary, in absolute sense the only, place.

\subsection{Intensifying the integration of the youth in the church through education}

We've already shown that God himself integrated the youth organically in His church by means of his covenant, lawful adoption or witnessing of faith and baptism. Teaching as a two-unit of word and deed training is one of the most important means (as already shown; e.g. 2.1 etc.) through which integration unfolds and intensifies. Schools can educate the children in Scripture and confession, but cannot take the place of the church, simply because it is not the body of Christ; this also applies to all other forms of education and training (e.g. courses). The church as body of Christ is the only institution that is truly able to watch comprehensively over the lambs in the flock. Other institutions can be partly of service at most (e.g. Gl $6: 1 \mathrm{f}$ ). The uniqueness of the church in this regard should be appreciated. A person who is not willing to join a church, or not willing to accept services from the church officials, acts against the ordained will of God (art 27, 28 Belgic Confession of Faith). 
With these statements the place of training in the church, as well as the meaning of church itself, are presented.

\subsection{Conclusion of Part two}

Training is a God-given method to develop the youth, who were planted by God himself into his church, and also a means by which they can grow to adult participation and service in church and world. The training consists of a two-unit of word and deed education. The necessity and command to train the youth (as well as adults), are evident in both the Old and New Testaments, as well as in the history of the church and synod decisions of all the churches present here today.

The Bible is the only source of content for this training. Part three will deal more explicitly with this aspect.

\section{THE PLACE OF THE BIBLE AND THE HOLY SPIRIT IN TRAINING IN THE CHURCH}

\subsection{The Bible as the voice of God and as His Shepherd's staff}

We are reasoning from the aprioric point of view that the Bible (66 Books) is God's infallible Word, inspired by the Holy Spirit (theopnéutos) ; $2 \mathrm{Pt1}: 20,21 ; 2 \mathrm{Tm} 3: 16$ ). The Bible is given in order to edify, train and educate $(2 \mathrm{Tm} 3: 16)$.

We take the stand that no authoritative or blessed education is possible without the Bible. A basic dictum in this regard is to be found in $1 \mathrm{Pt}$ 4: 11:

Whoever preaches,

must preach God's messages (Good News).

Literally this means: When one speaks (lalēin: talk) (it must be) as words of God (hōs loggia theôu).

God should therefore be heard through the voice of the speaker. Own knowledge, insight and wisdom carries no authority, and is rejected by the Holy Spirit (1 $\mathrm{Cr} 2: 18-2: 16$ ).

When God speaks, it is authoritative, gripping, penetrating, and it brings about change (Dt $28: 2-4 ;$ Js $55: 10: R m ~ 10: 10 \mathrm{f}: \mathrm{Hb} 4: 12 \mathrm{f}$ ). God's Word, and it alone, is the hammer shattering our hearts of stone ( $\operatorname{Jr} 23: 29$ ). No text book, manual, dogma or articles of faith, may replace the Bible as the Word of God; the Bible is given specially to educate and to train (2 $\mathrm{Tm} 3: 16,17)$ :

All Scripture is God-breathed

and is useful for teaching,

rebuking, correcting and training in righteousness,

so that the man of God may be thoroughly

equipped for every good work (New International Version).

What medicine means for the body, the Word of God means for the soul (Calvin). The Word of God is the staff with which the flock is lead (Bucer). When the Bible is used for education, it is implicated that the catechist will interpret the Bible (explicatio) and apply (applicatio) it, because gifts of speaking (1 Pt 4:10 f) is given specifically for this reason to the church (e.g. sermons of Peter: Ac $2: 14 \mathrm{f}$ and those of Stephen: Ac $7: 1 \mathrm{f}$ ). It is advisable for the catechists and other teachers in the church to cast a light on the ground pattern of the covenant, as it is reflected time and again in the Scripture as gifts of God (indicative), the commands to 


\section{In die Skriflig}

believers (imperative) and the promises of God. This three part classification opens up Scripture and puts reader/listener into a living relationship with God. Education should never evolve around doctrine, dogma or knowledge; but put us before the living God (e.g. $1 \mathrm{Sm} 3: 1 \mathrm{f}$ ). Education in the church is preaching. It should bring about a living and profound relationship between God and his child. In this regard the gift and activity of the Holy Spirit is indispensable.

Summarised: Church education has only the Bible as source. God himself speaks through the Bible, in the explanation and actualization (application) thereof to the smallest child. A good understanding of the covenant relationship with God is of utmost importance.

\subsection{The function of the Holy Spirit in proclaiming and receiving the Word of God}

Without the Holy Spirit the promulgation of the Word is doomed. The Holy Spirit not only gave the Word $(2 \operatorname{Tm} 3: 16)$, but is also the Interpreter thereof $(1 \mathrm{Cr} 2: 6-16)$. For this purpose Jesus and the Father sent the Spirit, to lead us and remind us of everything Jesus taught (Jn 14:26). A continuity of service exists between Jesus and the Spirit (Jn 14:18 f). He who dislocates Word and Spirit falls into bigotry (Calvin). The Holy Spirit has the Bible for his school (Calvin) and in this school the Holy Spirit stays the great 'magister' (Calvin).

We need to pray for the girt of the Holy Spirit (Lk 11:13); but it should also be seen to that his Word is ministered purely and sincerely, with humility and modesty ( $1 \mathrm{Pt} 3: 16$ ). The listener should manifest the correct attitude, and his heart should be directed completely towards God (Ps $50: 14 ; 1 \mathrm{Cr} 2: 6 \mathrm{f}$ ).

How dependent we are on the Holy Spirit is shown in Jn $20: 21-23$. Before Jesus sends out his disciples, he blessed them with the Holy Spirit (e.g. $1 \mathrm{Sm} 10: 8 ;$ Ps $50: 14$ ). Stephen also delivers his sermon while he is filled with the Spirit (Ac $7: 1 \mathrm{f} ; 1$ Th $5: 17 \mathrm{f}$ ).

Summarised: The service of the Spirit is indispensable for the proclaiming as well as receiving of church education.

The Holy Spirit leads and teaches the church through the Word, but demands obedience, surrendering and living with Him. Prayer, meditation and preparation forms important modes for the service of the Holy Spirit. The teacher himself must be filled with the Spirit.

\section{EVALUATION}

\subsection{Lack of real education in homes}

In many (most?) homes there is no continuity of training for the children. With this the most important way of training is made obsolete and today there is already a decadence to be seen in the churches.

Churches harbour too many untrue, un-Spiritfilled Christians: this bad ferment turns the whole of the dough sour $(2 \mathrm{Cr} 5 ; 5 \mathrm{f})$. Poor reading matter, over exposure to television, materialism, egotism and superficial religion have brought about that many homes cannot be called Bet-el (house of God).

Parents don't know the Bible any longer and cannot apply it in the general and specific education of their children. This deficiency is evi- 
dent in the fact that churches cannot succeed in finding office bearers. The structure of the church will have to change. A congregation cannot nowadays be kept sufficiently through two services on a Sunday, with catechism somewhere in between. Parents must change back into capable educators $(\mathrm{Rm} 15: 14)$.

Our religion again must become a way of life, inside and outside the home (Richards).

\subsection{Lack of real education in day schools}

The school and teacher should as much as possible be extensions of the home (Dordt, 1618/19). This is not always possible today (e.g. America, where even the Lord's Prayer is forbidden in schools).

The church may not depend on the school, it must complete its own task independently and in an adult way. In the case of rivalry in the school (where school education stands versus home education) parents will again be forced to find church schools. Fortunately this is not necessary in the RSA, because the spirit and character of schools are stipulated by parents (Law 39, 1969). It should be remembered though, that the church had experienced periods of prosperity in times of agnostic schools. Tertullian (160-220) wrote: no Christian can be a good school teacher in good conscience because of pagan strain. Nevertheless the church was flourishing.

Schools essentially teach Bible knowledge and are not able to integrate the child in the church as an organism, or to lead the child into dogmatic ground patterns as personal confession.

\subsection{Lack of education in the church today}

In a great number of churches too many text books are used and too little of the Bible. The following deficiencies are also pointed out:

- Pure knowledge is transferred, no 'preaching' takes place, the child isn't confronted with a personal decision regarding his faith;

- the training is applied too individually, the children aren't drawn together as a group in the koinonia of the church where they share their faith, pray together, sing together, and are engaged in a struggle for God (e.g. Cl $3: 16, \mathrm{Hb} 10: 23-25$ ). The children must function in the church as an organism;

- Sometimes the training is too dogmatic; it hangs in the air as 'eternal truths' and does not apply to the child's actual wants and needs. Put differently: catechism and other training in the church does not serve God's concrete herdmanship to his lambs;

- Many (most) catechists (help for the minister) are not trained and able to do this responsible work. Where use is made of helpers, training is a continual requirement;

- the church education doesn't succeed in drawing a social and cultural ground pattern. Today everything is relative, and the child lives in uncertainty. Rigorism is just as deadly as relativism, but a firm balance ought to be the goal and requirement. The youth must be both light and salt;

- many churches don't use the youngest and best techniques in education, for instance, the small group method, audiovisual apparatus, camps, or self study of the Scriptures with application. 


\section{EPILOGUE}

While studying I came anew under the impression of the importance of the Godly command to train his lambs into the church; to lead, to develop and integrate them: a difficult but glorious calling, because we only have to plant and to water. God Himself lets grow and sees to the bearing of fruit $(2 \mathrm{Cr} 3)$. The church lives and works in this expectation.

\section{BIBLIOGRAPHY}

Berkelbach van der Sprenkel, S.F.H.J. 1956. Handboek voor de praktische Theologie. Nijkerk: Callenbach.

Deputate Jeugsorg 1986. Jeugsorg in die Gereformeerde Kerke

De Vaux, R. 1973. Ancient Israel: It's life and Institutions. London: Darton, Longman and Todd.

De Villiers. D.W. 1957. Die Kategese in die Ned. Geref. Kerk in Suid-Afrika: 'n Prinsipiele, historiese en praktiese ondersoek van die Kategese in die Ned. Geref. Kerk in Suid-Afrika. Proefskrif: US.

Dijk, K. 1954. De dienst aan de kerkjeugd: Kort werkplan voor die catechese Kampen: Kok.

Handelinge van die Nasionale Sinodes, Gereformeerde Kerke in Suid-Afrika 1927; 1937; 1967; 1979.

Heitink, G. en Hogenhuis. H. 1980? Kerk en jongeren: werkboek ten dienst van het jeugd-en jongerenpastoraat. Kampen: Kok.

Louw, D.J. 1980. Die stad in die mens. Goodwood: NGK Boekhandel.

Ridderbos, H. 1966. Paulus: Ontwerp van zijn theologie. Kampen: Kok.

Richards, LO. 1983. A theology of children's ministry. Grand Rapids: Zondervan. Richards, LO. 1972. Youth ministry. Grand Rapids: Zondervan.

Zuck, R.B. and Clark, R.E. 1975. Childhood education in the Church. Chicago: Moody Press.

Van der Walt, J.J. 1976. Christus as Hoof van die Kerk en die presbiteriale kerkregering. Wetenskaplike bydraes, PU vir CHO. Reeks A: Nr. 21. 